УДК 378:373.2011.3-51

DOI: 10.37026/2520-6427-2019-100-4-111-115
Ірина ОНИЩУк,

кандидат педагогічних наук, доцент кафедри теорії і методики дошкільної та початкової освіти Кременецької обласної гуманітарно-педагогічної академії імені Тараса Шевченка

\title{
ЧИННИКИ РОЗВИТКУ КУЛЬТУРИ САМОВИРАЖЕННЯ МАЙБУТНІХ ВИХОВАТЕЛІВ ЗАКЛАДІВ ДОШКІЛЬНОЇ ОСВІТИ В ХУДОЖНІЙ ДІЯЛЬНОСТІ
}

У статті висвітлено одну з актуальних проблем сучасної вищої педагогічної освіти - підготовку фахівиів дошкільної освіти, оскільки саме від них залежатиме осучаснення підходів до освітнього процесу на першій освітній ланці. Основну увагу зосереджено на таких ключових питаннях, як особистісно-професійне становлення майбутнього фахівия, розвиток його культури самовираження, щзо передбачає наявність особливостей, способів і результатів самоорганізованої професійної діяльності. На основі аналізу психолого-педагогічної літератури визначено зовнішні та внутрішні чинники досліджуваного явища.

Ключові слова: особистісно орієнтована освіта, культура самовираження, майбутні вихователі закладів дошкільної освіти, художня діяльність, організаційно-педагогічні умови, чинники розвитку культури самовираження.

В статье освещена одна из актуальных проблем современноговысшегопедагогическогообразованияподготовка специалистов дошкольного образования, поскольку именно от них будет зависеть осовременнивание подходов к образовательному проиессу на первом образовательном звене. Основное внимание сосредоточено на таких ключевых вопросах, как личностно-профессиональное становление будущзего специилиста, развитие его культурь самовыражения, которое предполагает наличие особенностей, способов и результатов самоорганизуюшейся профессиональной деятельности. На основе анализа психолого-педагогической литературы определены внешние и внутренние факторы исследуемого явления.

Ключевые слова: личностно ориентированное образование, культура самовыражения, будущие воспитатели учреждений дошкольного образования, художественная деятельность, организационно-педагогические условия, факторы развития культуры самовыражения.
The article is devoted to the coverage of one of the topical issues of modern higher education - training of preschool education specialists, since today to a certain extent it will depend on them to modernize the approaches to the educational process at the first educational level. Attention is focused on such key issues as the personal and professional formation of a future specialist, the development of the culture of self-expression of a young person on the basis of the analysis of scientific works on philosophy, psychology and pedagogy.

The publication outlines the main aspects of research activities in the specified direction, namely: the purpose, the priority tasks and the scientifically substantiated ways of solving the problem are provided. The investigated phenomena are qualified as peculiarities, ways and results of self-organised professional activity. In particular, the structural components (cognitive, emotional, and behavioral) are specified on the basis of the nail of psychological and pedagogical literature; criteria and indicators of estimation of the formation of the culture of self-expression are singled out; criteria and indicators of estimation of the formation of the culture of self-expression, which are the characteristics of the personality of future specialists in preschool education, are singled out, corresponding to the main vectors of pedagogical activity (business, asciiological, communicative, transformative) and on this basis the typology of the formed phenomenon is determined.

In particular, special attention particular (special) attention is paid to the analysis of important factors in the development of culture self-expression of future specialists of preschool education; is paid to the clarification of organizational and pedagogical conditions, effective forms, methods and methods; outlines prospects for scientific intelligence.

It is also noted that the concept of research is ensured by the unity of methodological, theoretical and methodological aspects.

Key words: person-oriented education, culture of selfexpression, future educators of pre-school establishments, artistic activity, organizational and pedagogical conditions; self-expression factors of development in artistic activity. 
Постановка проблеми. Сучасний ринок праці вимагає від випускника закладу вищої освіти (далі 3BO) не лише глибоких теоретичних знань, а й здатності самостійно застосовувати їх у нестандартних, постійно змінюваних життєвих умовах, переходу від суспільства знань до суспільства життєво компетентних громадян. Таким чином, розбудова національної системи освіти майбутніх фахівців дошкільної сфери насамперед передбачає врахування викликів XXI століття, критичного осмислення досягнутого і зосередження основної уваги на розв'язанні найгостріших проблем, які стримують розвиток нової якості освіти, адекватної сучасній історичній епосі.

Отже, значущості набуває підготовка майбутнього вихователя закладу дошкільної освіти (далі-ЗДО), що дає змогу подолати однозначність та універсальну методичну рецептурність. За висновками науковців, професійна діяльність особистості - не лише одна 3 основних культурних цінностей та ключове завдання закладів вищої освіти, а й один із основних способів особистісної самореалізації людини, тобто іiі прагнення проявити себе. На часі важливою є проблема розвитку культури самовираження майбутнього педагога, зокрема й вихователя закладу дошкільної освіти.

Аналіз наукових досліджень і публікацій. Аспекти означеного нами феномену відображено в науковому доробку низки фахівців, серед яких: В. Андрущенко, І. Бех, О. Киричук, В. Кремень, І. Зязюн, В. Луговий, О. Сухомлинська та ін. (теоретико-методологічні засади організації освітнього процесу у вищій школі); Л. Артемова, Г. Бєлєнька, О. Богініч, А. Богуш, Н. Гавриш, Н. Гузій, I. Дичківська, Л. Зданевич, О. Кононко, І. Княжева, І. Луценко, Н. Лисенко, О. Лисенко, О. Листопад, О. Олійник, Ю. Косенко, Н. Маковецька, С. Нечай, І. Рогальська-Яблонська, Т. Танько та ін. (професійна підготовка майбутніх фахівців закладів дошкільної освіти); О. Берегова, І. Зязюн, А. Козир, Л. Левчук, О. Комаровська, Г. Локарєва, Л. Масол, Н. Миропольська, Г. Падалка, О. Рудницька, Г. Сотська, О. Отич, Г. Шевченко та ін. (естетико-педагогічні характеристики художньої культури).

Варто наголосити, що окремо проблема розвитку культури самовираження майбутніх вихователів ЗДО в художній діяльності досі ніким не вивчалася. Зважаючи на це, виникає потреба в дослідженні механізмів, виявленні чинників розвитку культури самовираження майбутніх фахівців дошкільної освіти в художній діяльності.

Мета статті - здійснити аналіз внутрішніх та зовнішніх чинників розвитку культури самовираження майбутніх вихователів закладів дошкільної освіти.

Виклад основного матеріалу. На констатувальному етапі дослідження нами було встановлено, що оптимізація освітнього процесу в закладах вищої освіти передбачає необхідність урахування у процесі підготовки майбутніх вихователів як зовнішніх, так і внутрішніх чинників, оскільки за відсутності їх балансу відбувається трансформація й уповільнення особистісного та професійного зростання. Зауважимо, що, оперуючи поняттям «внутрішні чинники», маємо на увазі індивідуальні особливості майбутніх вихователів ЗДО, які забезпечують зміни та прогресивний характер еволюції їхньої культури самовираження в художній діяльності. До них віднесено:

- особистісну та професійну самооцінки, їх співвідношення;
- потребу в зовнішній підтримці;

- інтерес до художньої діяльності, здібності до неї;

- самоповагу та саморегуляцію поведінки;

- суб'єктну оцінку оптимальної, бажаної та реальної міри розвитку культури самовираження;

- упевненість/невпевненість та залежність/незалежність активності досліджуваних.

У ході констатувального експерименту нами фіксувалися особливості впливу на досліджуване явище таких зовнішніх чинників, як:

- відображення проблеми формування в студентської молоді культури самовираження загалом та в художній діяльності зокрема, а також у змісті професійної підготовки майбутніх вихователів;

- інтеграція різних видів художньої діяльності та варіювання форм іiї організації;

- атмосфера у професійному оточенні;

- ставлення до успіхів та невдач досліджуваних значущих для них людей (викладачів, одногрупників);

- надання студентам права на вибір.

Відповідно до мети дослідження зупинимося на аналізі впливів на культуру самовираження майбутніх вихователів у художній діяльності внутрішніх чинників, пов'язаних 3 уявленнями досліджуваних про самих себе та майбутню професійну діяльність, умінням виробляти самооцінні судження, цінувати себе та регулювати власну поведінку. Перераховані вище суб' єктивні характеристики особистісного зростання дозволяють стверджувати про те, що розвиток кожної з них зокрема та всіх загалом визначається сформованістю в майбутніх вихователів позитивної й адекватної «Я-концепції».

За висновками фахівців, чим глибша самосвідомість особистості, тим ефективніше вона діє, адже усвідомлене ставлення до власних потреб, адекватна оцінка своїх можливостей і здібностей дозволяє студентові доцільно коректувати життєві сценарії. Як наслідок - адекватне уявлення майбутніх вихователів ЗДО про себе $є$ важливою умовою досягнення успіхів не лише в освітньому процесі взагалі, а й у самовираженні в художній діяльності. Слабка «Я-концепція» $є$ бар'єром у досягненні успіху внаслідок низької самооцінки та суб'єктивного, здебільшого досить обмеженого сприйняття майбутніми вихователями своїх особистісних властивостей, невисоких очікувань щодо себе [1; 4]. У ході аналізу емпіричних даних основну увагу нами було акцентовано на виділених провідними фахівцями базових компонентах «Я-концепції» досліджуваних, а саме: розумінні себе, впевненості у собі, емоиійній стійкості. Базуючись на них, характеризуватимемо особливості розвитку в майбутніх вихователів «Я-концепції» як важливої передумови розвитку культури самовираження.

Таким чином, зважаючи на викладене вище, можемо сформулювати такі узагальнення:

- порівнюючи оцінки знань досліджуваними себе як особистості та фахівця 3 упевненістю в собі й стійкістю емоцій, зауважимо, що система знань переважної більшості майбутніх вихователів ЗДО сформована краще, ніж довіра власним можливостям та саморегуляція емоцій та дій в освітньому процесі та художній діяльності;

- лише представники духовного та особистісного типів розвитку культури самовираження характеризуються високими оцінками саморозуміння, впевненості в собі та емоційної стабільності. Віднесені до суб'єктивного та базового типів культури самовираження 
студенти характеризувалися проміжними оцінками, які засвідчують їхню залежність від ситуації, складності та новизни завдання, необхідності виявити творчу ініціативу. Як і очікувалося, найнижчі оцінки отримали самооцінки, впевненість у собі та стійкість емоцій представників деструктивного типу - невпевнених у собі, імпульсивних досліджуваних, знання яких про себе виявилися клаптевими, схематичними, а самооцінки - невпевненими або низькими. Дехто 3 досліджуваних взагалі уникав необхідності оцінювати себе або відповідав так: «не знаю», «мені важко відповісти» тощо;

- близько 2/3 майбутніх вихователів визнали, що зазвичай невпевнені в собі, бояться помилитися, зробити щось неправильно, відчути на собі осуд авторитетних людей, зокрема викладачів, а також одногрупників. Вони усвідомлюють негативний вплив власної непевності на вміння культурно самовиражатися в освітньому процесі загалом та в художній діяльності зокрема. Отже, розвиток позитивної думки про себе важливий напрям подальшої роботи 3 даною категорією досліджуваних;

- більшість майбутніх вихователів зазначили, що успіх їхньої діяльності значною мірою залежить від зовнішніх впливів («знання та думки інших людей відіграють для мене важливу роль», «допомога інших позитивно позначається на результатах» тощо).

Наведені висловлювання засвідчують особливості оцінок представниками кожного типу розвитку культури самовираження значення реалізації «Я» у професійній діяльності. Узагальнюючи їх, схарактеризуємо типові для кожної категорії досліджуваних установки:

- духовний - масштабність, баланс індивідуального та соціального, прагнення до самовдосконалення;

- особистісний - визнання важливості самовизначення, реалізації власного потенціалу, орієнтація на цінності справедливості, щирості, власної гідності;

- суб'єктивний - визнання пріоритету результативних дій, активної взаємодії з колегами та дошкільниками, професійної етики;

- базовий - надання переваги дотриманню вимог і правил, проявам ввічливості й доброзичливості, необхідності бути для дітей зразком для наслідування;

- деструктивний - несформованість адекватної оцінки ролі самосвідомості в майбутній професійній діяльності.

Отже, актуалізується необхідність спеціальної організації освітньої роботи, спрямованої на вправляння майбутніх вихователів в уміннях адекватно себе оцінювати, поводитися впевнено та виявляти оптимізм під час виконання завдань художнього характеру. При цьому важливим є звернення до диференційованого підходу щодо розвитку самосвідомості представників трьох із п’яти типів культури самовираження - суб'єктного, базового та деструктивного. Це пояснюється необхідністю брати до уваги специфічні для кожної категорії досліджуваних особливості сформованості в них знань, ставлення та стилю поведінки в ситуаціях, які пред'являють вимоги до їхнього вміння культурно самовиражатися, діяти свідомо, впевнено, творчо.

Відповідно до логіки дослідження зупинимося на аналізі зовнішніх чинників, які вплинули на культуру самовираження майбутніх вихователів ЗДО у художній діяльності. До них віднесено:

- усвідомлення викладачами змісту й функцій художньої діяльності в сучасних реаліях;
- широту представленості та міру збалансованості в навчальних програмах видів художньої діяльності;

- урізноманітнення форм іiї організації у процесі підготовки майбутніх вихователів, надання досліджуваним права на творчість.

На сьогодні упровадження в закладах вищої освіти гуманістичної парадигми обумовило необхідність поглибленого аналізу особливостей організації художньої діяльності з метою залучення студентської молоді до духовної культури, діяльності зі створення духовних цінностей, реалізації власного творчого потенціалу, освоєння накопиченого соціального та духовного досвіду. Нас цікавило, наскільки художня діяльність досліджуваних спрямована на розвиток у них позиції суб'єкта, збагачення духовно-практичного ставлення до світу, окультурення потреб та плекання соціально прийнятних форм самовираження, зокрема і в художній діяльності.

Аналізуючи дані констатувального експерименту, ми виходили з розуміння, що в процесі професійної підготовки вихователів художній діяльності має приділятися ключова роль. Це, зокрема, пов'язано зі специфікою роботи вихователя, необхідністю опори на емоційно-чуттєвий досвід пізнання світу дітьми дошкільного віку. У процесі перетворювальної, духовно-пізнавальної, оціночної та комунікативної діяльностей майбутній вихователь ЗДО має оволодіти комплексом важливих художньо-педагогічних умінь: організовувати та управляти педагогічним процесом у його художньому втіленні, імпровізувати, усвідомлювати власну індивідуальність. У такий спосіб майбутній вихователь вдосконалюється як особистість, оволодіває здатністю ціннісно ставитися до своєї професійної педагогічної діяльності.

Зазначимо, що сучасні реалії, крім педагогічної, актуалізують ще й соиіальну функиіiю мистецтва та художньої діяльності. Твори мистецтва формують сферу культури українського суспільства загалом. Важливі самі по собі вони набувають особливого значення в аспекті їх соичіального функиіонування. Урахування в процесі підготовки майбутніх вихователів закладів дошкільної освіти соціальної компоненти художньої діяльності означає націленість викладачів закладів вищої освіти на культурне освоєння студентами соціального простору, виховання в них соціальної компетентності, збалансованість індивідуальних та колективних інтересів, формування вмінь працювати в команді (домовлятися, узгоджувати свої дії 3 іншими та брати до уваги їхні потреби, поступатися, приймати компромісні рішення, визнавати помилки та досягнення - як свої, так і інших людей, відстоювати свою думку тощо), не лише цінувати власні досягнення, а й презентувати їх широкому загалу.

Таким чином, удосконалення змісту освітніх програм передусім має базуватися на ідеї, відповідно до якої художня діяльність розуміється як складний феномен, що, з одного боку, має поєднувати психологічний, педагогічний та соціальний компоненти, а з іншого - функціонувати в процесі підготовки майбутніх вихователів на трьох рівнях - методологічному, діяльнісному, особистісному.

Висновки. Проведена на констатувальному етапі експерименту діагностика дозволила виявити в майбутніх вихователів ЗДО зовнішні та внутрішні чинники розвитку культури самовираження. Зокрема, до внутрішніх чинників нами віднесено особливості розвитку в досліджуваних самосвідомості (уявлення 
про себе як особистість та фахівця, характер самооцінки, ціннісне самоставлення), а до зовнішніх зміст та види художньої діяльності, їх інтеграцію в освітньому процесі, форми організації самостійної художньої діяльності студентів, надання їм права на прояв творчості.

Встановлено, що оптимізація освітнього процесу передбачає необхідність урахуваннях у процесі підготовки майбутніх вихователів ЗДО як зовнішніх, так і внутрішніх чинників, оскільки за відсутності їх балансу відбувається трансформація й уповільнення особистісного та професійного зростання студентської молоді.

Перспективу подальших наших досліджень вбачаємо у впровадженні моделі розвитку культури самовираження майбутніх вихователів ЗДО та визначенні їі ефективності.

\section{СПИСОК ВИКОРИСТАНОЇ ЛІТРРТУРИ}

1. Бех І. Д. Виховання особистості : в 2 кн. Кн. 2. Особистісно орієнтований підхід: науково-практичні засади / І. Д. Бех. - К. : Либідь, 2003. - 344 с.

2. Васильєва М. П. Культурологічний підхід до процесу професійної підготовки майбутнього педагога / М. П. Васильєва // Педагогіка і психологія творчої особистості: проблеми і пошуки : зб. наук. праць. Запоріжжя, 2007. - Вип. 47. - С. 67.

3. Зязюн I. А. Концептуальні засади теорії освіти в Україні / І. А. Зязюн // Педагогіка і психологія професійної освіти. - 2000. - № 1. - С. 11-24.
4. Кононко О. Л. Культура самовираження майбутніх педагогів як особистісний феномен / О. Л. Кононко // Психологія та педагогіка: необхідність впливу науки на розвиток практики в Україні : збірник тез наукових робіт учасників міжнар. наук.-практ. конф. Львів : ГО «Львівська педагогічна спільнота», 2017. C. $13-18$.

5. Кремень В. Г. Духовність і культура суспільства визначаються розвитком освіти / В. Г. Кремень // Освіта у полікультурних суспільствах / за ред. В. Кременя, Т. Лановицького, С. Нікіторовича, С. Сисоєвої.Варшава : Вища педагогічна школа СПВ, Університет Бялостоці, 2012. - С. 45-55.

6. Кримський С. Б. Культура розкриває внутрішню безмежність людини / С. Б. Кримський // Культурологічна думка. - 2009. - № 1. - С. 18-26.

7. Омельченко Е. А. Самовыражение и культура самовыражения педагогов и студентов педагогических вузов / Е. А. Омельченко // Теория и практика образования в современном мире : материалы II Международной научной конференции. - СПб. : Реноме, 2012. - С. 11-14.

8. Підготовка вихователя до розвитку особистості дитини в дошкільному віці : монографія / за заг. ред. I. І. Загарницької. - К. : Вид-во НПУ ім. М. П. Драгоманова, 2009. - $310 \mathrm{c}$.

9. Сисоєва С. О. Основи педагогічної творчості : підручник / С. О. Сисоєва. - К. : Міленіум, 2006. 344 c.

Дата надходження до редакиії: 08.10.2019 р. 